OPEN ACCESS

Edited by:

Maurizio Sanguinetti,

Catholic University of the Sacred

Heart, Italy

Reviewed by:

Nagendran Tharmalingam,

Rhode Island Hospital, United States

Yundong Sun

Shandong University, China

*Correspondence:

Yancheng Wen

hitwyc@qq.com

Feifei She

shefeifei@yeah.net

${ }^{t}$ These authors have contributed equally to this work

Specialty section:

This article was submitted to Infectious Diseases,

a section of the journal

Frontiers in Microbiology

Received: 24 November 2020

Accepted: 05 February 2021

Published: 25 February 2021

Citation:

XuX, Chen J, Huang $X$, Feng $S$,

Zhang $X$, She F and Wen $Y(2021$ )

The Role of a Dipeptide Transporter in the Virulence of Human Pathogen,

Helicobacter pylori.

Front. Microbiol. 12:633166.

doi: 10.3389/fmicb.2021.633166

\section{The Role of a Dipeptide Transporter in the Virulence of Human Pathogen, Helicobacter pylori}

\author{
Xiaohong $\mathrm{Xu}^{1,2,3 t}$, Junwei Chen ${ }^{1,2+}$, Xiaoxing Huang ${ }^{1,2}$, Shunhang Feng ${ }^{1,2}$, \\ Xiaoyan Zhang ${ }^{1,2}$, Feifei She ${ }^{1,2 *}$ and Yancheng Wen ${ }^{1,2 *}$

\begin{abstract}
${ }^{1}$ Key Laboratory of Gastrointestinal Cancer (Fujian Medical University), Ministry of Education, Fuzhou, China, ${ }^{2}$ Fujian Key Laboratory of Tumor Microbiology, Department of Medical Microbiology, Fujian Medical University, Fuzhou, China, ${ }^{3}$ Fujian Medical University Union Hospital, Fuzhou, China
\end{abstract}

Helicobacter pylori harbors a dipeptide (Dpp) transporter consisting of a substratebinding protein (DppA), two permeases (DppB and C), and two ATPases (DppD and F). The Dpp transporter is responsible for the transportation of dipeptides and short peptides. We found that its expression is important for the growth of $H$. pylori. To understand the role of the Dpp transporter in the pathogenesis of $H$. pylori, the expression of virulence factors and $H$. pylori-induced IL-8 production were investigated in $H$. pylori wild-type and isogenic $H$. pylori Dpp transporter mutants. We found that expression of CagA was downregulated, while expression of type 4 secretion system (T4SS) components was upregulated in Dpp transporter mutants. The DppA mutant strain expressed higher levels of outer membrane proteins (OMPs), including BabA, HopZ, OipA, and SabA, and showed a higher adhesion level to gastric epithelial AGS cells compared with the $H$. pylori 26695 wild-type strain. After infection of AGS cells, $H$. pylori $\triangle d p p A$ induced a higher level of NF- $\mathrm{B}$ activation and IL-8 production compared with wild-type. These results suggested that in addition to supporting the growth of $H$. pylori, the Dpp transporter causes bacteria to alter the expression of virulence factors and reduces $H$. pylori-induced NF-KB activation and IL-8 production in gastric epithelial cells.

\section{Keywords: Helicobacter pylori, dipeptide transporter, NF-кB, T4SS, outer membrane proteins}

\section{INTRODUCTION}

Helicobacter pylori is a microaerophilic, Gram-negative bacterium that is closely related to chronic gastritis, peptic ulcers, and gastric cancer (Kusters et al., 2006; Chmiela and Kupcinskas, 2019). To colonize the human stomach, $H$. pylori has to pass through the mucous layer to the surface of gastric mucosal epithelial cells via the movement of its flagella, and then colonizes the epithelial cells with the aid of adhesins (Sgouras et al., 2015). The pathogenesis of $H$. pylori is driven by several virulence factors that facilitate bacterial colonization, induce inflammation, and damage host cells. Among the virulence factors confirmed to function in H. pylori infection, Type 4 secretion system (T4SS) and its effector protein CagA encoded by cag pathogenicity island (cagPAI) are one of the most extensively studied $H$. pylori virulence factors (Guillemin et al., 2002; Sanchezzauco et al., 2013). cagPAI is about $40 \mathrm{~kb}$ in size and comprises 26 genes that encode the components of the 
T4SS. Relying on the T4SS, which binds to the $\alpha 5 \beta 1$ integrin expressed on the surface of gastric epithelial cells (Kwok et al., 2007), H. pylori delivers CagA, ADP-heptose (Pfannkuch et al., 2019), and peptidoglycan into host cells (Viala et al., 2004). H. pylori infection activates nuclear factor-kappa B (NF- $\kappa$ B) in gastric epithelial cells, inducing the release of proinflammatory factors such as interleukin 8 (IL-8) (Maeda et al., 2000; Backert and Naumann, 2010).

Successful colonization requires adaptation of the bacterium to the gastric environment. Environmental factors such as $\mathrm{pH}$, reactive oxygen species, temperature, or nutrients can affect the expression of $H$. pylori virulence factors (Merrell et al., 2003a; Pflock et al., 2006; Augusto et al., 2007; Noto et al., 2015). Acidic pH highly stimulates the expression of antioxidant proteins, flagellar structural proteins, and T4SS component proteins in H. pylori (Marcus et al., 2018). Upregulation of vacA and downregulation of genes related to motility were observed under iron-restricted conditions (Merrell et al., 2003b). Iron deficiency enhances $H$. pylori virulence; thus, $H$. pylori isolated from irondepleted gerbils expressed significantly higher levels of CagA, which induced more robust proinflammatory responses (Noto et al., 2012).

Considering that nutrients are important for the growth of bacteria, genes involved in the metabolism serve as targets for antimicrobial therapies. The peptide transporter systems have been extensively investigated in bacteria such as Escherichia coli and Lactococcus lactis (Sanz et al., 2001; Harder et al., 2008). Peptide transporters play an important role in nutritional supply by providing carbon sources or nitrogen sources for bacterial growth (Gilvarg, 1972). Three types of peptide transporters in bacteria have been found to date: oligopeptide (Opp) transporters, dipeptide (Dpp) transporters, and dip/tripeptide (Dtp) transporters (Garai et al., 2017). The Opp and Dpp transporters belong to the ATP-binding cassette $(\mathrm{ABC})$ superfamily, while the Dtp transporter belongs to the proton-dependent oligopeptide transporter (POT) (Paulsen and Skurray, 1994). The Dpp transporters are responsible for transporting mainly dipeptides but also tripeptides into cells (Payne and Smith, 1994), while the Opp transporters are responsible for the import of oligopeptides. The Dpp transporter in H. pylori is composed of five proteins encoded by $\operatorname{dp} p A, B, C, D$, and $F$ (Davis and Mobley, 2005; Weinberg and Maier, 2007). DppA is a periplasmic peptide-binding protein, $\mathrm{DppB}$ and $\mathrm{DppC}$ are integral membrane proteins that form permeases for substrates, while DppD and DppF are cytoplasmic proteins responsible for ATP hydrolysis.

Apart from being involved in the transport of nutrients, peptide transporters play a role in the virulence of various bacterial pathogens (Samen et al., 2004; Moraes et al., 2014). In E. coli, the Dpp transporter acts as a primary chemoreceptor, and its interaction with the membrane components for dipeptide chemotaxis initiates flagellar motion (Manson et al., 1986). In Borrelia burgdorferi, an opp mutant strain promotes the expression of the virulence factor OspC by regulating the Rrp2-RpoN-RpoS pathway (Zhou et al., 2018). In group A
Streptococci, Dpp mutation results in a decreased expression of SpeB, a major cysteine protease (Podbielski and Leonard, 1998). In Pseudoalteromonas, DppA plays an important role in cold adaptation (Zhang et al., 2010). However, hitherto the role of Dpp transporters in the growth and pathogenesis of $H$. pylori remains unknown. A study has shown that expression of DppA in $H$. pylori was stimulated by gastric epithelial cells, suggesting that DppA might play an important role in the pathogenesis of H. pylori (Sharma et al., 2010).

In this work, we constructed Dpp transporter mutants in $H$. pylori and evaluated the effects of the Dpp system on growth, expression of virulence factors, and inflammatory responses of AGS cells stimulated by $H$. pylori.

\section{MATERIALS AND METHODS}

\section{Bacterial Strains and Cultivation Conditions}

Helicobacter pylori 26695, NCTC11637 and Dpp transporter mutant strains were cultured in a microaerobic environment $\left(5 \% \mathrm{O}_{2}, 10 \% \mathrm{CO}_{2}\right.$, and $\left.85 \% \mathrm{~N}_{2}\right)$ at $37^{\circ} \mathrm{C}$ on Columbia agar plates (Oxoid, Cambridge, United Kingdom) containing 7\% sheep blood. For liquid cultivation of $H$. pylori, Brucella broth supplied with $10 \%$ fetal bovine serum (FBS) was used, and the strains were incubated in a shaker at $120 \mathrm{rpm}$ and $37^{\circ} \mathrm{C}$. A total of $5 \mu \mathrm{g} / \mathrm{ml}$ kanamycin (MP Biomedicals, CA, United States) was supplied when necessary.

\section{Construction of Isogenic $\Delta d p p A, \Delta d p p B$, $\Delta d p p C, \Delta d p p D, \Delta d p p F$ Mutants of $H$. pylori 26695 and Isogenic $\Delta d p p A$ Mutant of NCTC11637}

To construct a $d p p A$ knockout mutant of $H$. pylori 26695 $(\triangle d p p A)$, a DNA fragment containing an upstream sequence of $d p p A$ was amplified with the primers DppA-up-F and DppAup-R, a DNA fragment containing a downstream sequence of $d p p A$ was amplified with the primers DppA-down-F and DppA-down-R, and a DNA fragment containing AphA, which confers kanamycin resistance, was amplified with primers DppAKana-F and DppA-Kana-R. The $d p p A$ upstream sequence, $d p p A$ downstream sequence, and kanamycin resistance DNA fragments were ligated into a pBluescript II SK (-) vector (Novagen, Madison, WI, United States) using the ClonExpress MultiS One Step Cloning Kit (Vazyme, Nanjing, China), resulting in pBluscript-DppAKO, which was further transformed into E. coli $\mathrm{DH} 5 \alpha$. The plasmid sequence was then confirmed using colony PCR and Sanger sequencing. The pBluescript-DppAKO was then purified and subsequently transformed to $H$. pylori 26,695 by electroporation, and bacteria were then cultivated on agar plates containing kanamycin. $d p p A$ knockout mutants were further confirmed by colony PCR and Sanger sequencing. The construction of isogenic $H$. pylori 26695 mutants of $\triangle d p p B$, $\Delta d p p C, \Delta d p p D, \Delta d p p F$, and NCTC11637 $\Delta d p p A$ was conducted in a similar manner, and the primers used are listed in Table $\mathbf{1 .}$ 
TABLE 1 | Primers used in this study.

\begin{tabular}{|c|c|}
\hline Primers & Sequence $\left(5^{\prime}-3^{\prime}\right)$ \\
\hline \multicolumn{2}{|c|}{ For construction of isogenic mutants in $\mathrm{H}$. pylori 26,695} \\
\hline DppA-up-F & $\begin{array}{l}\text { AGGGCGAATTGGGTACCGAATTAGTGGAAGTGTTAG } \\
\text { CCGTAT }\end{array}$ \\
\hline DppA-up-R & $\begin{array}{l}\text { AACCGCCCAGTCTCGAGGATGGATTAAGAGT } \\
\text { AGCGTTGG }\end{array}$ \\
\hline DppA-down-F & 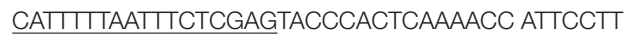 \\
\hline DppA-down-R & $\begin{array}{l}\text { GTGGCGGCCGCTCTAGATAAATCAGCATGAGCC } \\
\text { CTAGCC }\end{array}$ \\
\hline DppA-Kana-F & 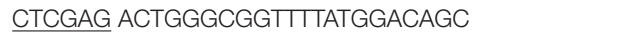 \\
\hline DppA-Kana-R & CTCGAG AAATTAAAAATGAAGTITAGC \\
\hline DppB-up-F & $\begin{array}{l}\text { TATAGGGCGAATTGGGTACCtGCGATCAATGCAG } \\
\text { ATGATTACATC }\end{array}$ \\
\hline DppB-up-R & AAAACCGCCCAGTAAACAGCGTGGGGATCGC \\
\hline DppB-down-F & ATITGATGTATATTGGGGCTAATCTCTTAG \\
\hline DppB-down-F & AGGAATTCGATATCAAGCTTGGGAGGTTGGGCCCCAA \\
\hline DppB-Kana-F & GCTGTIACTGGGCGGTITATGGACA \\
\hline DppB-Kana-F & $\begin{array}{l}\text { GCCCCAATATACATCAAAATTAAAAATGAAGTITAGCAC } \\
\text { GTG }\end{array}$ \\
\hline DppC-up-F & TATAGGGCGAATTGGGTACCTTGGCAACGCTTCCCGG \\
\hline DppC-up-R & $\frac{\text { GTCCATAAAACCGCCCAGTITGAATTGTTGGATAAAC }}{\text { TCTCTAAA }}$ \\
\hline DppC-down-F & TTGGATGCTTGTITCCCTGG \\
\hline DppC-down-R & $\begin{array}{l}\text { AGGAATTCGATATCAAGCTTACCACGCCTAAA TCATG } \\
\text { GGTG }\end{array}$ \\
\hline DppC-Kana-F & AACTGGGCGGTITATGGACA \\
\hline DppC-Kana-R & $\begin{array}{l}\text { CAGGGAAAACAAGCATCCAAAAATTAAAAATGA } \\
\text { AGTITAGCACGTG }\end{array}$ \\
\hline DppD-up-F & $\begin{array}{l}\text { TATAGGGCGAATTGGGTACCCGCCTITGAAGCCT } \\
\text { ATATGGG }\end{array}$ \\
\hline DppD-up-R & GCCCAGTCTTATCGGTGAAAAAATAAGTIITAAAT \\
\hline DppD-down-F & 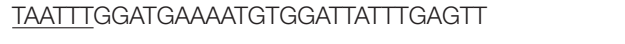 \\
\hline DppD-down-R & $\begin{array}{l}\text { AGGAATTCGATATCAAGCTTGCGCTTATCACGC } \\
\text { TATCCACA }\end{array}$ \\
\hline DppD-Kana-F & ITCACCGATAAGACTGGGCGGTITATGGACA \\
\hline DppD-Kana-R & $\begin{array}{l}\text { CCACATTTCATCCAAATTAAAAATGAAGTTाT } \\
\text { AGCACGTG }\end{array}$ \\
\hline DppF-up-F & $\begin{array}{l}\text { TATAGGGCGAATTGGGTACCAGGGTTGATTGAAA } \\
\text { AACCGGG }\end{array}$ \\
\hline DppF-up-R & CGCCCAGTTAGGCTTGAATAACCCCCTGTC \\
\hline DppF-down-F & TCCAAAGCACCCTTATACGCA \\
\hline DppF-down-R & $\begin{array}{l}\text { AGGAATTCGATATCAAGCTTAAGCCCTTCC } \\
\text { CTCGCTAGC }\end{array}$ \\
\hline DppF-Kana-F & ATTCAAGCCTAAACTGGGCGGTITATGGACA \\
\hline DppF-Kana-R & $\begin{array}{l}\text { GCGTATAAGGGTGCTTGGAAAATTAAAAATGA } \\
\text { AGTITAGCACGTG }\end{array}$ \\
\hline \multicolumn{2}{|c|}{ For construction of isogenic mutant in NCTC11637 } \\
\hline DppA-up-F & $\frac{\text { TATAGGGCGAATTGGGTACCACTATAATAAGCGTTA }}{\text { TITTAAAAAGAGCG }}$ \\
\hline DppA-up-R & AAAACCGCCCAGTCATAAGCCAGTCTCCACAACAAAT \\
\hline DppA-down-F & TAGCCTATCCTTATTCGGTGGTG \\
\hline DppA-down-R & $\begin{array}{l}\text { AGGAATTCGATATCAAGCTTAGTGCTTGATCGTATC } \\
\text { CATAAACG }\end{array}$ \\
\hline DppA-Kana-F & GCTTATGACTGGGCGGTITATGGACA \\
\hline DppA-Kana-R & $\frac{\text { CACCGAATAAGGATAGGCTAAAATTAAAAATGAAG }}{\text { TITAGCACGTG }}$ \\
\hline
\end{tabular}

(Continued)
TABLE 1 | Continued

\begin{tabular}{|c|c|}
\hline Primers & Sequence $\left(5^{\prime}-3^{\prime}\right)$ \\
\hline \multicolumn{2}{|l|}{ For qPCR } \\
\hline $\operatorname{Cag} \delta-\mathrm{F}$ & GTGCTATGGGGATTGTTGGGATA \\
\hline $\operatorname{Cag} \delta-R$ & TTGCTTGAGATTITGAGTTCG \\
\hline CagV-F & GGCTIITATCTCTCTATGGCACTC \\
\hline CagV-R & САATITTAAАTTCTCCTGTGTATCG \\
\hline CagU-F & AAAAGCTACCGCAAGAAAAAAGG \\
\hline CagU-R & AAACAAAACAAATATCCCACCCA \\
\hline CagS- $F$ & CAAGGGAGCGTTAGATAAGGTTCT \\
\hline CagS-R & АATTAGGATTCTCTGCAATGGCAT \\
\hline CagQ-F & CCGAACAAGCAAGAACTTACACAAC \\
\hline CagQ-R & TCATTAACATCAGGAAGAACAAAAA \\
\hline CagP-F & АСААТТСАААСАТТСТТТААСАA \\
\hline CagP-R & GATAAACTAAAATCACCCCTGCCC \\
\hline CagM-F & AAACAAATACAAAAAAGAAAAAGAGG \\
\hline CagM-R & AAACATAGGCATAAGGGTTAGGAAGA \\
\hline CagC-F & GGGTCAAAGGCATAGCGGATAT \\
\hline CagC-R & GAAGCCAAACTTAGTGCTCAAA \\
\hline CagA-F & GCCACTACTACCACCGACATACAAGG \\
\hline CagA-R & GTCAGCGACTCCCTCAACATCTAACA \\
\hline CagL-F & TGCTGAGCAACAATGCGGAATATCC \\
\hline CagL-R & GCGTCTGTGAAGCAGTGATTAAGGAA \\
\hline 16s rRNA-F & GGCGACCTGCTGGAACATTACTGAC \\
\hline 16s rRNA -R & CCAGGCGGGATGCTTAATGCGTTAG \\
\hline AlpA-F & CGGTGCGACTGGTTCAGATGGT \\
\hline AlpA-R & AGCGGCTACGGCAGAGTTGAAA \\
\hline AlpB-F & GGCTTACGCTACTACGGCTTCTTCA \\
\hline AlpB-R & CCCGCATTAAGACTTCGGCTACCAA \\
\hline HopZ-F & GCAAACACGCAAGGGCTGATTGG \\
\hline HopZ-R & СTCTTACCAGGACCGCATTGGACAT \\
\hline BabA-F & GCACTGGTGGCACACAAGGTTCA \\
\hline BabA-R & CGGCTTGCTGTATCTGCTGCTCTT \\
\hline SabA-F & GCACCACCCAATCGCCCATCTITA \\
\hline SabA-R & ACACTAGCGGGTTGCCCACTATCA \\
\hline HopQ-F & GCGTTGAGATCGGTGTTAGGGCTAT \\
\hline HopQ-R & TGCCATTGCCATTCTCATCGGTGTA \\
\hline HpaA-F & GAGAGCGATGCGCTTAGCGAAGA \\
\hline HpaA-R & CGCCGCAATTCCACTCTTTCAATCA \\
\hline OipA-F & GCCGATTCGCAGGAAATGGTGGA \\
\hline OipA-R & AACCGCTACCAGGAACAGAACCAAC \\
\hline SabB-F & CCACTGGTCCTGTAACCGACTATGC \\
\hline SabB-R & GAGATCCTGTGGCTTGAGCTTGCA \\
\hline IL-8-F & GAAGGTGCAGTITGCCAAG \\
\hline IL-8-R & TाTCTGTGTTGGCGCAGTG \\
\hline GAPDH-F & AAATTCCATGGCACCGTCAAG \\
\hline GAPDH-R & GGACTCCACGACGTACTCAG \\
\hline
\end{tabular}

Underlined part indicates overlapping DNA sequences.

\section{Cell Lines, Cultivation, and Co-culture of AGS Cells and $\boldsymbol{H}$. pylori Strains}

The human gastric epithelial AGS cell line (derived from a human gastric adenocarcinoma) was cultured in a DMEM/F12 medium (HyClone Laboratories Inc., Logan, UT, United States), with supplementation of 10\% FBS (PANS, Aidenbach, Bayern, 
Germany) at $37^{\circ} \mathrm{C}$ in a $5 \% \mathrm{CO}_{2}$ humidified atmosphere. For H. pylori infection assays, AGS cells were grown in 6-well plates (NUNC, Thermo, DE, United States) until the confluence reached 75\% in DMEM/F12 medium containing 10\% FBS. Before infection, the supernatant was removed, and cells were washed twice with phosphate-buffered saline (PBS), followed by culture in FBS-free DMEM/F12 for $4 \mathrm{~h}$. H. pylori strains were first cultivated on agar plates; then, the bacteria were collected and resuspended in Brucella broth at an initial $\mathrm{OD}_{600}$ of 0.1 , followed by culture for $24 \mathrm{~h}$. Bacterial cells were then pelleted and washed twice with DMEM/F12 medium, resuspended in DMEM/F12 medium, and added to the AGS cell culture at a multiplicity of infection (MOI) of 100 .

\section{Determination of Bacterial Growth Rates}

To monitor the growth of $H$. pylori strains, bacteria were first cultivated on Columbia agar plates for 3 days, followed by collection of bacterial cells and resuspension in Brucella broth at an initial $\mathrm{OD}_{600}=0.1$. Next, the bacteria were cultured at $37^{\circ} \mathrm{C}$ with agitation. The $\mathrm{OD}_{600}$ values of the bacterial culture were recorded every $8 \mathrm{~h}$. Each experiment was repeated at least three times.

\section{RNA Sequencing and Data Analysis}

To prepare total RNA for transcriptomic study, $H$. pylori 26,695 and $\triangle d p p A$ cells were cultivated in Brucella broth containing $10 \%$ FBS for $20 \mathrm{~h}$ until reaching the exponential phase in a shaker at $120 \mathrm{rpm}$ in a microaerobic environment $\left(5 \% \mathrm{O}_{2}, 10 \% \mathrm{CO}_{2}\right.$, and $\left.85 \% \mathrm{~N}_{2}\right)$ at $37^{\circ} \mathrm{C}$. Total RNA was isolated using the RNeasy Mini Kit (QIAGEN, Valencia, CA, United States). RNA degradation and contamination were monitored on $1 \%$ agarose gels. RNA sequencing was carried out at Novogene (Beijing, China), and RNA purity was confirmed using a NanoPhotometer spectrophotometer (IMPLEN, CA, United States). RNA concentration was measured using the Qubit RNA Assay Kit with a Qubit 2.0 Flurometer (Life Technologies, CA, United States). RNA integrity was assessed using the RNA Nano 6000 Assay Kit for the Agilent Bioanalyzer 2100 system (Agilent Technologies, CA, United States). Ribosomal RNA (rRNA) was then depleted using the Ribo-zero kit (Ambion, Thermo, DE, United States) in accordance with the manufacturer's instructions. Sequencing libraries were generated using the NEBNext Ultra Directional RNA Library Prep Kit for Illumina (NEB, Ipswich, MA, United States) following the manufacturer's recommendations, and index codes were added to attribute sequences to each sample. The clustering of the indexcoded samples was performed on a cBot Cluster Generation System using the TruSeq PE Cluster Kit v3-cBot-HS (Illumina, San Diego, CA, United States). After cluster generation, the library preparations were sequenced on an Illumina Hiseq platform, and paired-end reads were generated. The resulting $P$-values were adjusted using the Benjamini and Hochberg's approach for controlling the false discovery rate. Genes with an adjusted $P$-value $<0.05$ found by DESeq were designated as differentially expressed. The data were deposited in the NCBI
Gene Expression Omnibus database $\left(\mathrm{GEO}^{1}\right)$ under accession number GSE164216.

\section{RNA Isolation and Quantitative RT-PCR}

To prepare bacterial RNA samples, bacteria were grown in Brucella broth containing 10\% FBS for $20 \mathrm{~h}$, which was followed by extraction of total RNA using a RNeasy Mini Kit (QIAGEN, Valencia, CA, United States) in line with the manufacturer's instructions. In order to extract RNA from AGS cells or AGS cells infected with $H$. pylori, the cells were collected after co-culture with bacteria at $37^{\circ} \mathrm{C}$ in a $5 \% \mathrm{CO}_{2}$ humidified atmosphere after infection with $H$. pylori using TRIzol reagent (Life Technologies, Carlsbad, CA, United States) according to the manufacturer's instructions. RNA concentration and purity were then determined by spectrophotometry (NanoDrop One, Thermo, DE, United States). For quantitative RT-PCR (qPCR) analysis, cDNA was prepared through reverse transcription using $1 \mu \mathrm{g}$ of total RNA and the HiScript II Q RT SuperMix for qPCR (+gDNA wiper) kit (Vazyme, Nanjing, China). qPCR assays were carried out using the SYBR qPCR Master Mix kit (Vazyme, Nanjing, China). Specific primers for each gene indicated were designed with Primer 5.0 and are listed in Table 1. Genes encoding 16S rRNA were used as endogenous controls, and relative RNA levels were calculated using the $2^{-\Delta \Delta C t}$ method. Experiments were performed in triplicate for each condition.

\section{Bacterial Pulldown Assays}

Helicobacter pylori was grown in Brucella broth containing 10\% FBS for $20 \mathrm{~h}$, after which the bacterial cells were washed twice and resuspended in PBS. Approximately $3 \times 10^{7}$ cells were incubated with $\alpha 5 \beta 1$ integrin $(250 \mu \mathrm{g} / \mathrm{mL})$ (R\&D Systems, Minneapolis, $\mathrm{MN}$, United States) for $30 \mathrm{~min}$ at $37^{\circ} \mathrm{C}$ with rotation. In order to measure the amount of $\alpha 5 \beta 1$ integrin bound by $H$. pylori, the samples were centrifuged at $6,000 \mathrm{rpm}$ for $10 \mathrm{~min}$. Bacterial cells were collected, washed twice with PBS, and then resuspended in $1 \times$ SDS loading buffer (60 mM Tris- $\mathrm{HCl}$ [pH 6.8], 2\% SDS $10 \mathrm{ml}, 10 \%$ glycerol, $100 \mathrm{mM}$ DTT, $0.01 \%$ bromophenol blue). After denaturation by boiling for $10 \mathrm{~min}$, the samples were resolved on a $10 \%$ SDS-polyacrylamide gel (SDS-PAGE). Western blot with an anti- $\beta 1$ Rabbit antibody (1:1000; Cell Signaling Technology, Danvers, MA, United States) was performed as described previously.

\section{Bacteria Protein Extraction and Western Blotting}

To determine the expression of CagA, H. pylori cells were harvested after $20 \mathrm{~h}$ culture in Brucella broth containing $10 \%$ FBS. The cells were then washed twice with PBS, and total lysates were obtained using RIPA lysis buffer (Beyotime, Shanghai, China). The concentration of proteins was determined using a BCA Protein Assay Kit (Beyotime, Shanghai, China). Protein samples were then subjected to electrophoresis using a $10 \%$ SDS-PAGE gel and subsequently transferred to PVDF membranes (Millipore, Darmstadt, Germany) for antibody

\footnotetext{
${ }^{1}$ http://www.ncbi.nlm.nih.gov/geo
} 
blotting. Membranes were blocked with Tris buffered saline containing $0.1 \%$ Tween-20 (TBST) containing 5\% BSA. The membranes were then probed with an anti-CagA (b-10) antibody (1:800; Santa Cruz Biotechnology, Dallas, TX, United States), followed by an m-IgGкBP-HRP secondary antibody (1:1500; Santa Cruz Biotechnology, Dallas, TX, United States).

\section{Adhesion Tests}

AGS cells were seeded in 6-well plates at a density of $3.5 \times 10^{5}$ cells/well with $2 \mathrm{ml}$ of DMEM/F12 to form a confluent monolayer, and then infected with $H$. pylori at an MOI of 100 as described above. After 4 h of infection, the AGS cells were washed three times with PBS to remove any unattached bacteria. To determine the number of adherent $H$. pylori, the AGS cells were lysed using $0.1 \%$ saponin for $20 \mathrm{~min}$ at room temperature. After a serial dilution, $50 \mu$ l of each diluted cell lysate containing bacteria was placed on a Columbia sheep blood plate. Subsequently, the bacteria were incubated under microaerobic condition $\left(5 \% \mathrm{O}_{2}\right.$, $15 \% \mathrm{CO}_{2}$, and $75 \% \mathrm{~N}_{2}$ ) for 4 days, and colonies were counted.

\section{Dual-Luciferase Reporter Assay}

$\mathrm{NF}-\kappa \mathrm{B}$ activation was determined using luciferase reporter assays. AGS cells were seeded in 12 -well plates at a density of $5 \times 10^{5}$ cells/well in $1 \mathrm{ml}$ DMEM/F12 with FBS and cultured overnight. Subsequently, $1 \mu \mathrm{g}$ of pNL3.2.NF-кB-RE (Promega, Madison, WI, United States) and $0.1 \mu \mathrm{g}$ of pRL-TK (Promega, Madison, WI, United States) were co-transfected into these AGS cells using Lipofectamine 3000 (Invitrogen, Carlsbad, CA, United States) following the manufacturer's instruction. After $48 \mathrm{~h}$ of culture, the cells were infected with $H$. pylori strains at an MOI $=100$. After infection for $4 \mathrm{~h}$, the AGS cells were harvested, and luciferase activities were measured using the Dual-Luciferase Reporter Assay System (Promega, Madison, WI, United States) in accordance with the manufacturer's instruction. Each result represents the mean of three independent experiments.

\section{IL-8 Secretion Assays}

The AGS cells were seeded in 6-well culture plates at a density of $3.5 \times 10^{5}$ per well in $2 \mathrm{ml} \mathrm{DMEM} / \mathrm{F} 12$ medium with FBS to form a confluent monolayer. After $20 \mathrm{~h}$ of culture, the supernatant was replaced with fresh DMEM/F12 without serum after washing with $1 \times$ PBS to starve cells for $4 \mathrm{~h}$. Next, the cells were infected with $H$. pylori 26,695 at an MOI of 100 or infected with NCTC11637 at an MOI of 30. After $4 \mathrm{~h}$ of infection, the supernatant was harvested, and IL-8 concentration was measured using enzyme linked immunosorbent assay (ELISA) with a Human IL-8 ELISA kit (BD Biosciences, San Jose, CA, United States) in line with the manufacturer's instructions.

\section{Statistical Analysis}

All data were presented as the mean \pm the standard error of mean. An unpaired $t$-test was used for comparisons between the two groups. Graph-Pad Prism 7.0 (La Jolla, CA, United States) was used to plot the data, and $P<0.05$ was considered statistically significant.

\section{RESULTS}

\section{Dpp Transporters Are Important for the Growth of $\boldsymbol{H}$. pylori}

Five genes were studied, $d p p A, B, C, D$, and $F$, which encode a dipeptide (Dpp) transporter comprising two permeases, two ATPases, and a substrate-binding protein (Davis and Mobley, 2005). To study the role of Dpp transporters in the virulence of H. pylori, we first constructed isogenic mutants of $d p p A, d p p B$, $d p p C, d p p D$, and $d p p F$ in $H$. pylori 26,695, and then assessed the impact of the Dpp transporter on bacterial growth. Growth curves showed that $H$. pylori 26,695 $\Delta d p p A, \Delta d p p B, \Delta d p p C$, $\triangle d p p D$, and $\Delta d p p F$ strains proliferated slower than a wild-type strain (Figures 1A-E). Specifically, $D p p F$ had the strongest effect on the growth of $H$. pylori, suggesting its important role in the bacterial growth. We also constructed a $\triangle d p p A$ mutant in the $H$. pylori strain NCTC11637 and conducted the same experiment. The $\Delta d p p A$ mutant grew slower compared with the NCTC11637 wild type (Figure 1F). The results indicated that the importance of the Dpp system for the growth of $H$. pylori.

\section{Transcriptomic Profiling of Gene Expression in $H$. pylori Wild-Type and $\Delta d p p A$ Strains}

To further examine the roles of DppA, we performed RNAseq analysis and investigated the genes expressed differentially between $H$. pylori 26695 and a $\triangle d p p A$ strain. We found that 253 genes were differentially expressed with a $\mid \log _{2}$ (fold change) $\mid>1$, including 116 genes that were upregulated and 137 genes that were downregulated in $\triangle d p p A(P<0.05)$ (Figure 2A). These genes are listed in Table 2. We also performed functional classification of the genes upregulated and downregulated in $\triangle d p p A$ (Figure 2B). We found that genes involved in energy metabolism, cellular processes, transportation, and translation were significantly downregulated in $\triangle d p p A$, which might contribute to the decreased growth rate of $H$. pylori in this genetic background. Genes involved in DNA metabolism, bacterial pathogenesis, and motility were upregulated in this strain, and they might contribute to the virulence of $H$. pylori.

\section{The Dpp Transporter Activates the Expression of CagA}

The transcriptomic study revealed differential expression of $H$. pylori virulence genes, especially those involved with cagPAI, between the wild-type and $\triangle d p p A$ strain. In this study, we focused on those virulence factors that are closely related to the cellular inflammatory response. We first investigated the expression of CagA at both the mRNA and protein levels. The qPCR results showed that CagA mRNA levels in $\triangle d p p A$, $\Delta d p p B, \Delta d p p C, \Delta d p p D$, and $\Delta d p p F$ strains were lower than in the H. pylori 26,695 wild-type strain (Figure 3A). CagA protein expression was also investigated, and similar results were obtained, i.e., CagA expression was repressed in $\triangle d p p A$, $\Delta d p p B, \Delta d p p C, \Delta d p p D$, and $\Delta d p p F$ strains (Figures $3 \mathbf{B}, \mathbf{C}$ ). This was also shown in the NCTC11637 background, as 
A

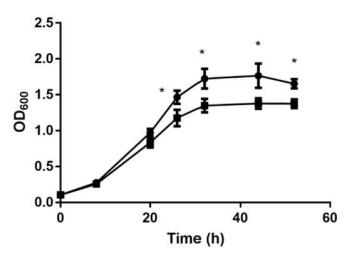

D

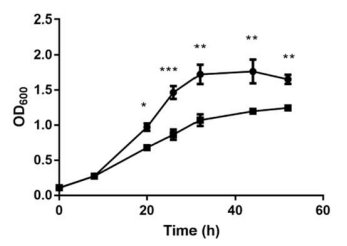

B
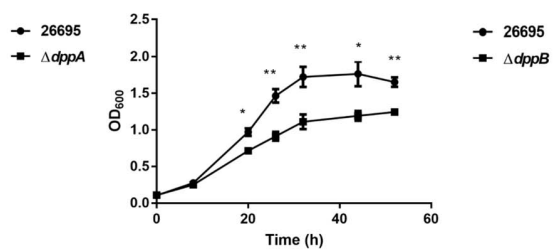

E

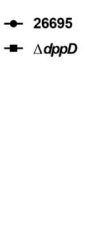

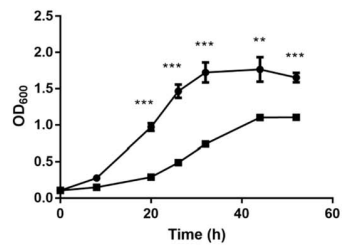

C

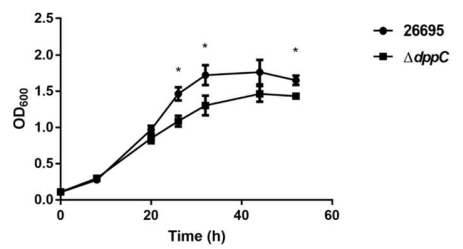

$\mathbf{F}$

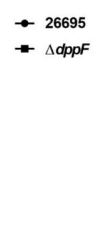

FIGURE 1 | Growth of $H$. pylori wild-type strains and Dpp transporter mutant strains. Growth curves of $H$. pylori 26695 compared to its isogenic mutants $\triangle d p p A$ (A), $\Delta d p p B$ (B), $\Delta d p p C$ (C), $\Delta d p p D$ (D), and $\Delta d p p F$ (E). (F) Growth curve of H. pylori NCTC11637 compared with its isogenic mutant $\Delta d p p A$. Data shown represent average means from three independent experiments, and standard deviations are also indicated. ${ }^{\star \star \star} P<0.001,{ }^{\star \star} P<0.01,{ }^{\star} P<0.05$.

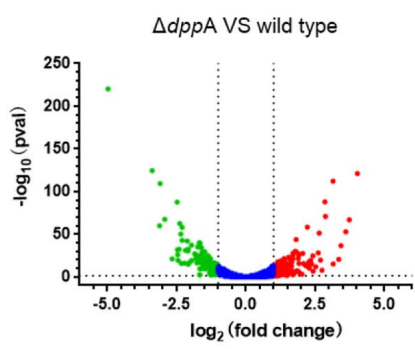

$\rightarrow$ NCTC11637

- $\triangle$ dppa
- Upregulated: 116 - Downregulated: 137

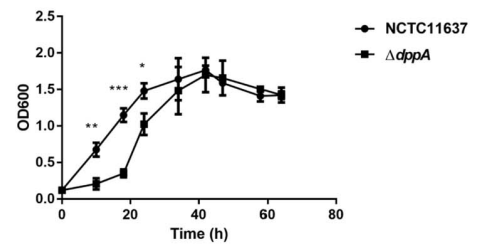


TABLE 2 | Differentially expressed genes identified by RNA-seq.

\begin{tabular}{|c|c|c|c|}
\hline Gene expression & Gene no. & $\begin{array}{l}\text { Gene name or } \\
\text { function }\end{array}$ & $\log _{2}$ (fold change) \\
\hline \multirow[t]{50}{*}{ Upregulated } & HP0059 & Predicted gene & 2.4264 \\
\hline & HP0114 & Predicted gene & 1.3287 \\
\hline & HP0115 & flaB & 1.7312 \\
\hline & HP0116 & topA & 1.378 \\
\hline & HP0117 & Predicted gene & 1.3026 \\
\hline & HP0119 & Predicted gene & 2.2661 \\
\hline & HP0131 & Predicted gene & 1.7324 \\
\hline & HP0132 & sdaA & 1.2527 \\
\hline & HP0140 & $\operatorname{lct} P$ & 1.1428 \\
\hline & HP0142 & mutY & 1.0653 \\
\hline & HP0143 & Predicted gene & 1.0272 \\
\hline & HP0230 & kdsB & 1.2419 \\
\hline & HP0260 & $\bmod$ & 1.4971 \\
\hline & HP0261 & Predicted gene & 1.1733 \\
\hline & HP0262 & Predicted gene & 1.128 \\
\hline & HP0263 & hpaim & 1.3069 \\
\hline & HP0328 & IpxK & 1.5594 \\
\hline & HP0329 & nadE & 1.03 \\
\hline & HP0342 & Predicted gene & 1.4897 \\
\hline & HP0343 & Predicted gene & 2.741 \\
\hline & HP0346 & Predicted gene & 1.4341 \\
\hline & HP0366 & $\begin{array}{l}\text { Spore coat } \\
\text { polysaccharide } \\
\text { biosynthesis protein } \mathrm{C}\end{array}$ & 2.1667 \\
\hline & HP0367 & Predicted gene & 1.6527 \\
\hline & HP0373 & Predicted gene & 2.8507 \\
\hline & HP0388 & tRNA methyltransferase & 1.2813 \\
\hline & HP0394 & Predicted gene & 1.0201 \\
\hline & HP0428 & Predicted gene & 2.0485 \\
\hline & HP0430 & Predicted gene & 1.7632 \\
\hline & HP0431 & ptc1 & 2.2646 \\
\hline & HP0432 & Predicted gene & 2.4158 \\
\hline & HP0434 & Predicted gene & 2.3603 \\
\hline & HP0440 & topA & 1.307 \\
\hline & HP0441 & VirB4 homolog & 1.5219 \\
\hline & HP0453 & Predicted gene & 1.505 \\
\hline & HP0462 & hsdS & 1.5466 \\
\hline & HP0463 & hsdM & 1.5851 \\
\hline & HP0472 & omp11 & 1.916 \\
\hline & HP0483 & Predicted gene & 1.0174 \\
\hline & HP0522 & cag3 & 1.0262 \\
\hline & HP0524 & cag5 & 1.5355 \\
\hline & HP0525 & $\operatorname{cag} \alpha$ & 1.6885 \\
\hline & HP0526 & CagZ & 1.2767 \\
\hline & HP0527 & cag7 & 2.8708 \\
\hline & HP0538 & cag17 & 1.4644 \\
\hline & HP0543 & cag22 & 1.1474 \\
\hline & HP0601 & flaA & 3.1409 \\
\hline & HP0602 & Endonuclease III & 1.881 \\
\hline & HР0603 & Predicted gene & 2.5156 \\
\hline & HP0611 & Predicted gene & 1.6473 \\
\hline & HP0613 & $\begin{array}{l}\text { ABC transporter } \\
\text { ATP-binding protein }\end{array}$ & 1.1885 \\
\hline
\end{tabular}

TABLE 2 | Continued

\begin{tabular}{|c|c|c|c|}
\hline Gene expression & Gene no. & $\begin{array}{l}\text { Gene name or } \\
\text { function }\end{array}$ & $\log _{2}$ (fold change) \\
\hline & HP0621 & mutS2 & 1.1332 \\
\hline & HP0638 & Membrane protein & 1.1037 \\
\hline & HP0651 & Fucosyltransferase & 1.4555 \\
\hline & HP0652 & serB & 1.9143 \\
\hline & HP0666 & glpC & 1.321 \\
\hline & HP0673 & Predicted gene & 1.131 \\
\hline & HP0675 & xerC & 1.6417 \\
\hline & HP0690 & fad $A$ & 1.1721 \\
\hline & HP0711 & Predicted gene & 1.6394 \\
\hline & HP0713 & Predicted gene & 2.6885 \\
\hline & HP0728 & Predicted gene & 1.2074 \\
\hline & HP0751 & flaG & 2.6091 \\
\hline & HP0752 & fliD & 2.6449 \\
\hline & HP0753 & flis & 1.2148 \\
\hline & HP0754 & $\begin{array}{l}\text { 5-formyltetrahydrofolate } \\
\text { cyclo-ligase }\end{array}$ & 2.0228 \\
\hline & HP0755 & Predicted gene & 1.3991 \\
\hline & HP0757 & $\begin{array}{l}\text { Beta-alanine } \\
\text { synthetase homolog }\end{array}$ & 1.2021 \\
\hline & HP0758 & Membrane protein & 1.8156 \\
\hline & HP0759 & Membrane protein & 1.6024 \\
\hline & HP0821 & uvrC & 1.3838 \\
\hline & HP0846 & hsdR & 1.8459 \\
\hline & HP0860 & gmhB & 1.369 \\
\hline & HP0896 & omp19 & 1.8089 \\
\hline & HP0897 & Predicted gene & 1.124 \\
\hline & HP0922 & Membrane protein & 1.2871 \\
\hline & HP0939 & yckJ & 1.4377 \\
\hline & HP0941 & alr & 1.331 \\
\hline & HP0942 & $\operatorname{dag} A$ & 1.1314 \\
\hline & HP0943 & $\operatorname{dadA}$ & 1.293 \\
\hline & HP0985 & Predicted gene & 1.0004 \\
\hline & HP1000 & Para & 1.4507 \\
\hline & HP1002 & Predicted gene & 1.3929 \\
\hline & HP1017 & rocE & 1.704 \\
\hline & HP1020 & ispDF & 1.2427 \\
\hline & HP1021 & cheY & 1.6902 \\
\hline & HP1022 & Predicted gene & 1.0345 \\
\hline & HP1027 & fur & 1.1997 \\
\hline & HP1047 & rbfA & 1.0606 \\
\hline & HP1051 & Predicted gene & 1.1447 \\
\hline & HP1080 & Membrane protein & 1.3598 \\
\hline & HP1081 & Predicted gene & 1.5337 \\
\hline & HP1095 & $\operatorname{tnp} B$ & 1.4743 \\
\hline & HP1119 & flgK & 3.4284 \\
\hline & HP1120 & Predicted gene & 3.1475 \\
\hline & HP1121 & BSP6IM & 1.8938 \\
\hline & HP1148 & trmD & 1.1276 \\
\hline & HP1165 & tetA & 1.2466 \\
\hline & HP1167 & Predicted gene & 4.0239 \\
\hline & HP1215 & Predicted gene & 1.2189 \\
\hline & HP1233 & Predicted gene & 2.281 \\
\hline & HP1238 & amiF & 1.387 \\
\hline
\end{tabular}


TABLE 2 | Continued

\begin{tabular}{|c|c|c|c|}
\hline Gene expression & Gene no. & $\begin{array}{l}\text { Gene name or } \\
\text { function }\end{array}$ & $\log _{2}$ (fold change) \\
\hline & HP1258 & Predicted gene & 1.0603 \\
\hline & HP1321 & ATP-binding protein & 1.45 \\
\hline & HP1390 & Predicted gene & 3.3507 \\
\hline & HP1391 & Predicted gene & 1.915 \\
\hline & HP1440 & Predicted gene & 3.7316 \\
\hline & HP1505 & Predicted gene & 1.123 \\
\hline & HP1519 & Predicted gene & 2.1358 \\
\hline & HP1523 & recG & 1.2919 \\
\hline & HP1589 & Predicted gene & 1.091 \\
\hline & HPr05 & HPrrnB5S & 1.2855 \\
\hline & HPt01 & tRNA-Glu-1 & 1.7745 \\
\hline & HPt08 & tRNA-Asn-1 & 1.3011 \\
\hline & HPt25 & tRNA-Ser-1 & 1.3979 \\
\hline & HPt26 & tRNA-Pro-1 & 1.697 \\
\hline & HPt36 & tRNA-Phe-1 & 2.3394 \\
\hline \multirow[t]{36}{*}{ Downregulated } & HP0003 & kdsA & -1.0474 \\
\hline & HP0004 & icfA & -1.4707 \\
\hline & HP0010 & groEL & -1.7937 \\
\hline & HP0011 & groES & -1.2866 \\
\hline & HP0015 & Predicted gene & -1.0676 \\
\hline & HP0033 & clpA & -1.0831 \\
\hline & HP0035 & Predicted gene & -1.1771 \\
\hline & HP0036 & Predicted gene & -1.1712 \\
\hline & HP0057 & Predicted gene & -2.2975 \\
\hline & HP0072 & ureB & -1.48 \\
\hline & HP0073 & ureA & -1.5839 \\
\hline & HP0091 & hsdR & -1.0385 \\
\hline & HP0099 & tlpA & -1.1019 \\
\hline & HP0100 & Predicted gene & -1.0583 \\
\hline & HP0102 & Predicted gene & -1.5088 \\
\hline & HP0103 & tlpB & -1.5548 \\
\hline & HP0109 & dnaK & -1.8288 \\
\hline & HP0110 & GrpE & -1.142 \\
\hline & HP0111 & Predicted gene & -1.1914 \\
\hline & HP0118 & Predicted gene & -1.3158 \\
\hline & HP0145 & fixO & -1.0377 \\
\hline & HP0153 & recA & -1.5738 \\
\hline & HP0154 & eno & -1.0973 \\
\hline & HP0157 & arok & -1.7674 \\
\hline & HP0213 & gid $A$ & -2.3523 \\
\hline & HP0229 & omp6 & -1.3943 \\
\hline & HP0243 & napA & -1.9605 \\
\hline & HP0289 & ImaA & -1.3117 \\
\hline & HP0290 & lysA & -1.5474 \\
\hline & HP0291 & Predicted gene & -1.2657 \\
\hline & HP0292 & Predicted gene & -1.0587 \\
\hline & HP0294 & amiE & -2.2148 \\
\hline & HP0296 & rplU & -1.4814 \\
\hline & HP0297 & rpmA & -1.4635 \\
\hline & HP0298 & dppA & -4.9784 \\
\hline & HP0299 & $\mathrm{dppB}$ & -1.4717 \\
\hline
\end{tabular}

TABLE 2 | Continued

\begin{tabular}{|c|c|c|c|}
\hline Gene expression & Gene no. & Gene name or function & $\log _{2}$ (fold change) \\
\hline & HP0300 & $\mathrm{dppC}$ & -2.088 \\
\hline & HP0301 & dppD & -2.4619 \\
\hline & HP0302 & $\mathrm{dppF}$ & -2.0374 \\
\hline & HР0303 & obgE & A-3.1174 \\
\hline & HP0304 & Predicted gene & -2.0838 \\
\hline & HP0318 & Predicted gene & -1.2903 \\
\hline & HP0364 & nrdF & -1.1763 \\
\hline & HP0377 & dsbC & -1.3781 \\
\hline & HP0378 & ycf5 & -1.1151 \\
\hline & HP0390 & $\operatorname{tag} \mathrm{D}$ & -2.3061 \\
\hline & HP0415 & Predicted gene & -2.9304 \\
\hline & HP0514 & rpll & -1.1937 \\
\hline & HP0515 & hsIV & -1.2219 \\
\hline & HP0609 & Predicted gene & -1.0705 \\
\hline & HP0616 & cheV & -1.1044 \\
\hline & HP0620 & ppa & -1.0328 \\
\hline & HP0625 & ispG & -1.0162 \\
\hline & HP0630 & $\mathrm{mdaB}$ & -1.6352 \\
\hline & HP0641 & Predicted gene & -1.6672 \\
\hline & HP0663 & aroC & -1.1477 \\
\hline & HP0677 & Predicted gene & -1.0215 \\
\hline & HP0680 & $\operatorname{nrdA}$ & -1.1181 \\
\hline & HP0681 & Predicted gene & -1.0098 \\
\hline & HP0682 & Predicted gene & -2.3295 \\
\hline & HP0686 & fecA & -1.1601 \\
\hline & HP0696 & $\mathrm{N}$-methylhydantoinase & -1.1476 \\
\hline & HP0718 & Predicted gene & -1.2217 \\
\hline & HP0761 & Predicted gene & -1.1174 \\
\hline & HP0777 & pyrH & -1.6091 \\
\hline & HP0783 & Predicted gene & -1.133 \\
\hline & HP0789 & Predicted gene & -1.0537 \\
\hline & HP0807 & fecA & -1.1454 \\
\hline & HP0810 & $\mathrm{rsmD}$ & -1.102 \\
\hline & HP0811 & Predicted gene & -2.0849 \\
\hline & HP0824 & ahpc & -1.201 \\
\hline & HP0829 & guaB & -1.6093 \\
\hline & HP0830 & gatA & -2.1157 \\
\hline & HP0834 & engA & -1.0829 \\
\hline & HP0876 & frpB & -2.1815 \\
\hline & HP0959 & Predicted gene & -1.1905 \\
\hline & HP0960 & glyQ & -1.6042 \\
\hline & HP0961 & gpsA & -3.3854 \\
\hline & HP0983 & Predicted gene & -1.2053 \\
\hline & HP1023 & Predicted gene & -1.1999 \\
\hline & HP1029 & Predicted gene & -1.2139 \\
\hline & HP1036 & folk & -1.5392 \\
\hline & HP1037 & Predicted gene & -1.2796 \\
\hline & HP1038 & aroQ & -1.0187 \\
\hline & HP1055 & Predicted gene & -1.3617 \\
\hline & HP1077 & nixA & -1.3528 \\
\hline & HP1098 & Predicted gene & -1.0557 \\
\hline & HP1114 & uvrB & -1.6187 \\
\hline
\end{tabular}


TABLE 2 | Continued

\begin{tabular}{|c|c|c|c|}
\hline Gene expression & Gene no. & Gene name or function & $\log _{2}$ (fold change) \\
\hline & HP1162 & Predicted gene & -2.3026 \\
\hline & HP1164 & $\operatorname{trxB}$ & -1.1085 \\
\hline & HP1177 & hopQ & -1.657 \\
\hline & HP1180 & nupC & -1.273 \\
\hline & HP1181 & Multidrug transporter & -1.2283 \\
\hline & HP1186 & $\operatorname{arsR}$ & -1.2884 \\
\hline & HP1212 & atpE & -1.662 \\
\hline & HP1283 & Predicted gene & -1.4378 \\
\hline & HP1286 & Predicted gene & -1.6787 \\
\hline & HP1288 & Predicted gene & -2.66 \\
\hline & HP1289 & Predicted gene & -1.3261 \\
\hline & HP1323 & rnhB & -2.4111 \\
\hline & HP1324 & Predicted gene & -1.2158 \\
\hline & HP1325 & fumC & -1.2411 \\
\hline & HP1326 & Predicted gene & -1.9589 \\
\hline & HP1327 & Predicted gene & -2.4519 \\
\hline & HP1333 & Predicted gene & -1.1022 \\
\hline & HP1334 & Predicted gene & -1.3602 \\
\hline & HP1338 & nikR & -1.3032 \\
\hline & HP1372 & MreC & -1.0638 \\
\hline & HP1395 & omp30 & -1.8492 \\
\hline & HP1404 & hsdS & -1.0096 \\
\hline & HP1420 & flil & -1.2893 \\
\hline & HP1459 & Predicted gene & -1.0261 \\
\hline & HP1465 & HI1087 & -1.3993 \\
\hline & HP1468 & ilvE & -2.3918 \\
\hline & HP1469 & omp31 & -1.6033 \\
\hline & HP1483 & ubiE & -1.1526 \\
\hline & HP1484 & Membrane protein & -1.0726 \\
\hline & HP1487 & Predicted gene & -1.0692 \\
\hline & HP1488 & Predicted gene & -1.0942 \\
\hline & HP1496 & ctc & -1.1262 \\
\hline & HP1501 & omp32 & -1.6835 \\
\hline & HP1508 & Ferredoxin-like protein & -1.4878 \\
\hline & HP1512 & Predicted gene & -1.685 \\
\hline & HP1526 & lexA & -1.0048 \\
\hline & HP1534 & TnpB & -1.2819 \\
\hline & HP1550 & $\sec D$ & -1.4823 \\
\hline & HP1551 & yajC & -1.1451 \\
\hline & HP1561 & ceuE & -1.1216 \\
\hline & HP1563 & tsaA & -1.7381 \\
\hline & HP1582 & $p d x J$ & -2.4696 \\
\hline & HP1583 & $p d x A$ & -1.7959 \\
\hline & HP1588 & Predicted gene & -3.0945 \\
\hline & HPt06 & tRNA-Val-2 & -1.1089 \\
\hline & HPt07 & tRNA-Ser-3 & -2.4847 \\
\hline & HPt19 & tRNA-Arg-4 & -1.6638 \\
\hline & HPt27 & tRNA-Ser-2 & -1.0814 \\
\hline & HPt34 & tRNA-Leu-2 & -1.6756 \\
\hline
\end{tabular}

We also tested the $\triangle d p p C$ background, and found that all 10 genes from each operon were expressed more in $\triangle d p p C$ than in wild-type strain. During infection, CagA or LPS metabolites were delivered through the T4SS to gastric epithelial cells, and this was dependent on the direct interaction between T4SS proteins and $\alpha 5 \beta 1$ integrins (Kwok et al., 2007). To investigate if the Dpp transporter also influenced the binding of T4SS to $\alpha 5 \beta 1$ integrin, a bacterial pulldown assay using purified $\alpha 5 \beta 1$ integrin was performed, and we measured the amount of $\alpha 5 \beta 1$ integrin bound by $H$. pylori. The results showed that the $\triangle d p p A$ strain bound significantly more $\alpha 5 \beta 1$ integrin compared with H. pylori 26,695 wild-type strain (Figures 4D,E). These results suggested that deficiency in Dpp transporter resulted in a higher expression of T4SS genes and an increase in T4SS binding to $\alpha 5 \beta 1$ integrin.

\section{The Dpp Transporter Causes Lower Expression of Outer Membrane Proteins and Reduces the Adhesion of $\boldsymbol{H}$. pylori to AGS Cells}

Our transcriptomic study revealed that several outer membrane proteins related to adhesion were differentially expressed in $\triangle d p p A$ strain. This suggested that the Dpp transporter might play an important role in bacterial adhesion. To test this hypothesis, we first confirmed the expression of the OMPs involved in bacterial adhesion. Our results showed that, compared with H. pylori 26,695, the expression of adhesion genes (babA, hopZ, $o i p A$, and $s a b A$ ) was higher in a $\triangle d p p A$ strain, while alpAB, hpaA, $h o p Q$, and $s a b B$ showed similar expression levels between the wild-type and $\triangle d p p A$ strains (Figure $\mathbf{5 A}$ ). This suggested that DppA caused a lower expression of OMPs. We also investigated the expression of OMPs in $\Delta d p p B, \Delta d p p C, \Delta d p p D$, and $\Delta d p p F$ strains, and showed higher expression of BabA, HopZ, OipA, and SabA than in wild-type (data not shown), which confirmed that the Dpp transporter causes a lower expression of OMPs. Next, to verify whether the Dpp transporter altered the adhesion of $H$. pylori to AGS cells, AGS cells were infected with $H$. pylori 26,695 wild-type and $\triangle d p p A$ cells; subsequently, we investigated the number of bacteria bound to AGS cells. Our results showed that $\triangle d p p A$ cells had a higher binding capacity compared with wild-type 26,695 cells (Figure 5B). H. pylori NCTC11637 and its isogenic mutant $\triangle d p p A$ were also analyzed, and we found that in the H. pylori NCTC11637 strain, deletion of $d p p A$ also resulted in a higher bacterial adhesion level (Figure 5C). This suggested that in $H$. pylori, the Dpp transporter caused a reduced expression level of OMPs, including $b a b A, h o p Z$, oipA, and sabA, thereby reducing the adhesion of $H$. pylori to AGS cells.

\section{The Dpp Transporter Inhibits $H$. pylori Activation of Gastric Epithelial NF- $\kappa$ B}

Upon adhesion to AGS cells, $H$. pylori directly activates NF$\kappa \mathrm{B}$ through the T4SS, which delivers the effector protein CagA, peptidoglycan, or ADP-heptose to cells. We investigated the effect of the Dpp transporter on $H$. pylori-induced NF- $\mathrm{KB}$ activation in AGS cells. We performed a dual-luciferase reporter assay using an NF-кB-luc reporter plasmid. After $4 \mathrm{~h}$ of infection with $H$. pylori, NF-кB was activated in wild-type infected cells. We also found that $\triangle d p p A, \Delta d p p B, \Delta d p p C$, and $\Delta d p p D$ infection activated NF$\kappa \mathrm{B}$ to a level $50 \%$ higher than infection with a wild-type strain (Figure 6A). However, infection with the $\Delta d p p F$ strain failed to activate NF- $\kappa B$, likely due to low activity of $\Delta d p p F$ for its low 
A

CagA

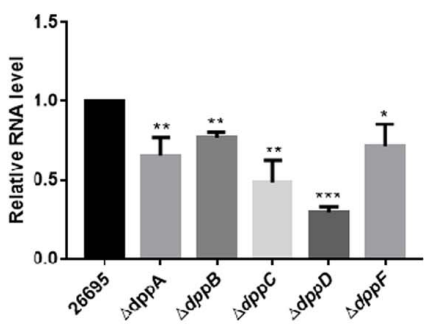

B

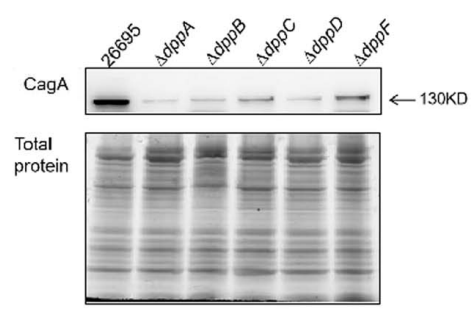

D

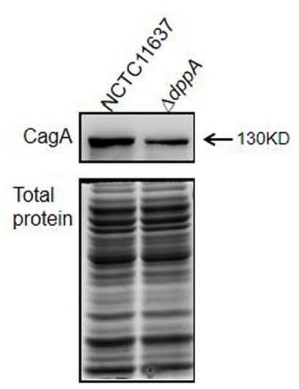

E

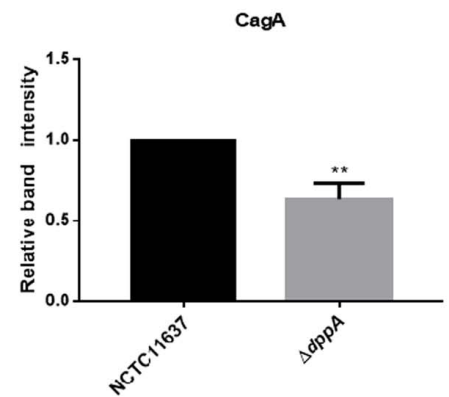

C

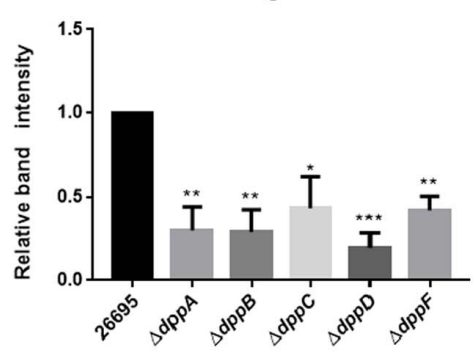

FIGURE 3 | Effects of DppA on the expression of CagA. (A) mRNA level of CagA expressed in H. pylori 26,695 and Dpp transporter mutant strains. Values represent the relative mRNA level of CagA normalized to H. pylori 26,695. (B-D) CagA expression level determined by Western blot. Total protein represents the cell lysate resolved by SDS-PAGE. Protein bands representing CagA are indicated, and the position of a $130 \mathrm{kDa}$ size marker is indicated by an arrow. (C,E) Quantification analysis of CagA bands. Densitometry was normalized to total protein. Values are shown as averages $\pm \mathrm{SD}(n=3) .{ }^{\star \star \star} P<0.001,{ }^{\star \star} P<0.01,{ }^{\star} P<0.05$.

A

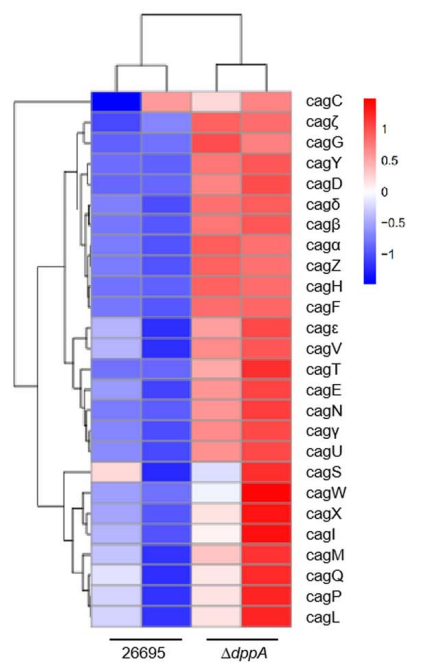

B

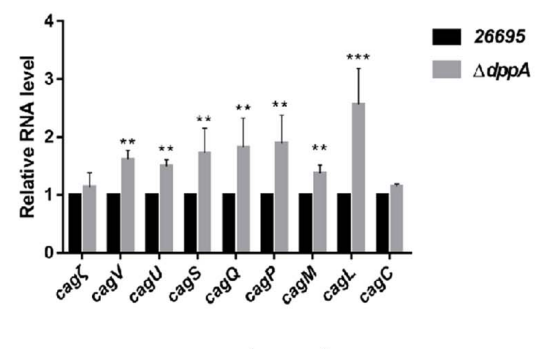

D

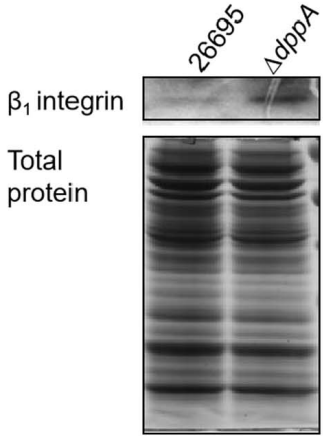

C

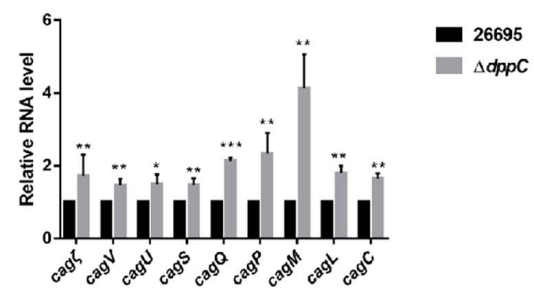

E

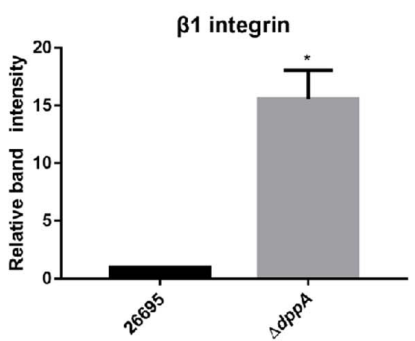

FIGURE 4 | Effects of DppA on the expression of CagT4SS. (A) Hierarchical cluster analysis of T4SS gene expression in 26,695 and $\triangle d p p A$ strains. (B) Determination of mRNA levels of T4SS components in $H$. pylori 26,695, $\triangle d p p A$, and $\triangle d p p C$ (C). Values represent the relative mRNA level of each gene normalized to $H$. pylori 26,695 . (D) $\alpha 5 \beta 1$ integrin bound by $H$. pylori 26,695 and $\triangle d p p A$. Bands representing $\beta 1$ integrin are indicated, and total bacterial protein load is shown. (E) Quantification analysis of $\beta 1$ integrin bands. Densitometry was normalized to total protein. ${ }^{\star * \star} P<0.001,{ }^{* *} P<0.01,{ }^{*} P<0.05$. 
A

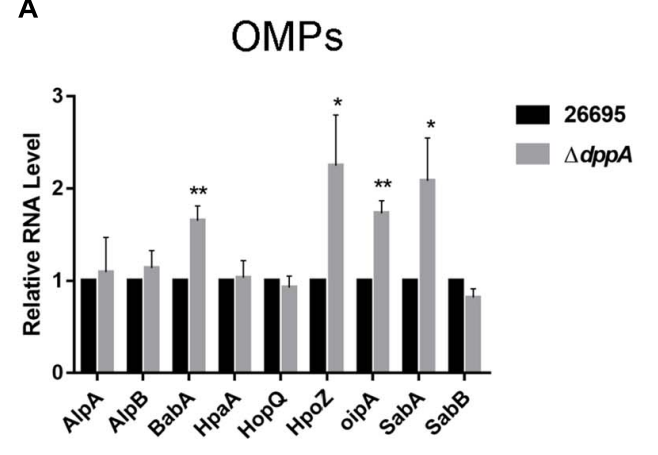

B

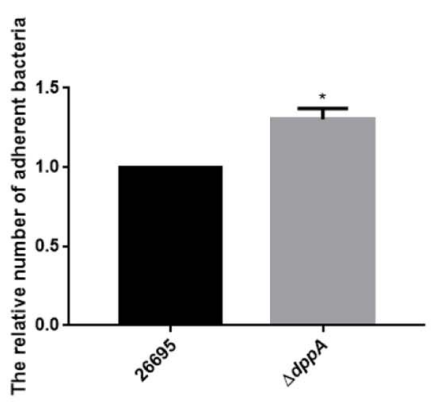

C

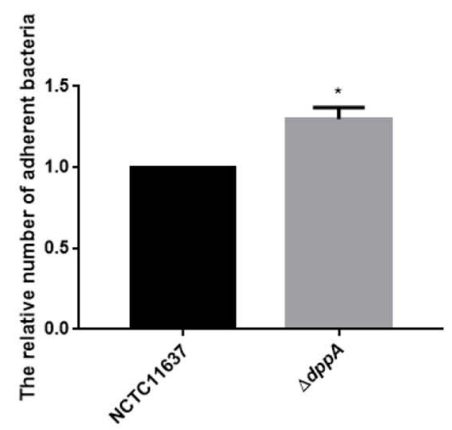

FIGURE 5 | Effects of DppA on the adherence of $H$. pylori to AGS cells. (A) qPCR study of the expression of OMPs in $H$. pylori 26,695 and its isogenic mutant $\triangle d p p A$. Adherence of $H$. pylori to AGS cells. Relative adherence represents the number of $\Delta d p p A$ cells adherent to AGS cells normalized to $H$. pylori 26,695 (B) and NCTC11637 (C). Data shown are the average values from three independent experiments, and bars represent standard deviations. ${ }^{\star \star} P<0.01,{ }^{\star} P<0.05$.

growth ability as shown in Figure 1E. We also checked $H$. pylori NCTC11637 and its isogenic mutant $\triangle d p p A$, and found that NF$\kappa \mathrm{B}-l u c$ was expressed at a level $70 \%$ higher than in wild type (Figure 6B). This suggested that the Dpp transporter in H. pylori reduced the ability to activate NF- $\kappa \mathrm{B}$ in AGS cells. Activation of NF- $\kappa \mathrm{B}$ directly induces the expression of the inflammatory factors, including IL-8 (Brandt et al., 2005). Thus, we next utilized by ELISA and qPCR to examine IL- 8 expression in AGS cells infected by $H$. pylori. Our results showed that IL- 8 expression in AGS cells induced by $H$. pylori $\Delta d p p A, \Delta d p p B, \Delta d p p C$, and $\triangle d p p D$ was significantly higher than that induced by wild-type H. pylori 26,695 (Figures 6C,D). As shown in Figure 6A, $\Delta d p p F$ failed to activate the expression of IL- 8 in AGS cells. In $H$. pylori $11,637, \Delta d p p A$ also induced a higher level of IL-8 expression compared with wild-type $H$. pylori NCTC11637 (Figures 6E,F). This indicated that the Dpp transporter repressed NF- $\kappa$ B and IL-8, thereby reducing the inflammatory response of AGS cells induced by $H$. pylori.

Taken together, this work was the first study to show the role of the Dpp transporter in the regulation of virulence of H. pylori. Our study demonstrated that the Dpp transporter is important for the growth of $H$. pylori, suggesting that dipeptides might serve as an important nutrient source for this bacterium. Although Dpp transporter-deficient strains proliferated slower, they were associated with higher bacterial adhesion and T4SS expression and induced a stronger inflammatory response in AGS cells. The Dpp transporter also activated the expression of CagA, illustrating the complex role of Dpp transporters in subtle control of bacterial virulence.

\section{DISCUSSION}

The host tissue is a rich source of nutrients for bacteria, providing nutrients such as sugars and amino acids. To acquire the nutrients from host, pathogens produce specific virulence factors and causes host damage. It is important to understand the interaction between metabolism and bacterium pathogenesis since bacterial growth is the main goal for the pathogen to colonize in the host (Rohmer et al., 2011). Peptide transporters are important to acquire carbon from host sources for pathogen's growth. Moreover, these transporters are also responsible for importing environmental cues to coordinate bacterial behavior (Garai et al., 2017). Human pathogens always face various environmental stresses, such as temperature variation, $\mathrm{pH}$, nutrient changes, and oxidative stress (Shao et al., 2005). Understanding these transporters and their cognate substrates may help in unraveling the mechanisms of bacterial adaptation through changes in bacterial behavior, including virulence.

In this study, we found that the Dpp transporter was important for the bacterial growth (Figure 1). However, H. pylori $\triangle d p p D$ and $\triangle d p p F$ grew significantly slower compared to wild type, $\Delta d p p A, \Delta d p p B$, or $\Delta d p p C$ cells. $\mathrm{DppD}$ and $\mathrm{DppF}$ are both dipeptide ABC transporter ATP binding subunits, which suggests that $\triangle d p p D$ and $\triangle d p p F$ might completely abolish the function of Dpp transporters, resulting in a shortage of nutrients. Specifically, we noticed that the $\Delta d p p F$ strain grew much slower compared with other strains. DppF acts as an ABC transporter ATP binding subunit, which might be critical for the growth of H. pylori, causing $\triangle d p p F$ with its decreased capacity to induce an inflammatory response in AGS cells (Figures 6A,C,D).

In this study, we found that the CagA expression was largely dependent on the expression of the Dpp transporter (Figure 3). During the infection of gastric epithelial cells, H. pylori translocates CagA using the T4SS. Through interactions with $\mathrm{SH} 2$ domains, CagA activates their function to promote the Ras-Erk signaling pathway to activate oncogenesis of gastric epithelial cells (Tohidpour, 2016; Hatakeyama, 2017; Naumann et al., 2017). The CagA protein is strongly associated with development of gastric cancer, and regulation of CagA expression is closely related to gastric cancer development (Hatakeyama, 2017). Studies have shown that CagA expression varies depending on the growth stage and conditions (Karita et al., 1996). It has also been shown that high-salt concentrations induce the expression of CagA, which is related to gastric cancer development. Iron and $\mathrm{pH}$ also regulate CagA expression (Odenbreit et al., 1999). 
A

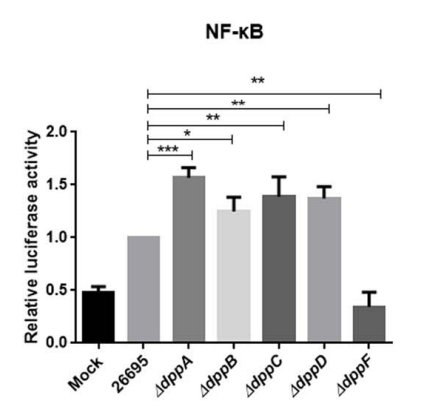

D

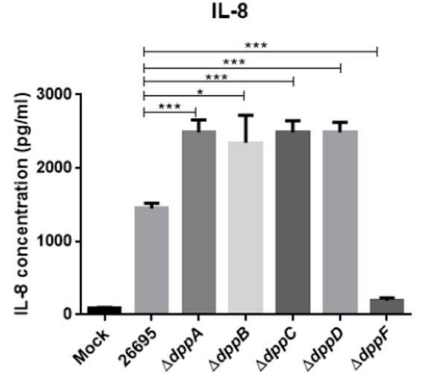

B

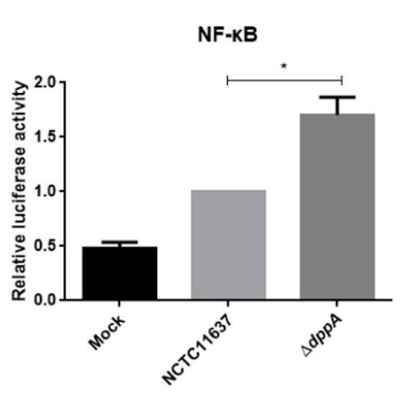

E

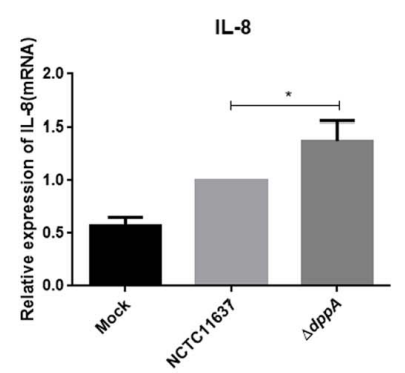

C

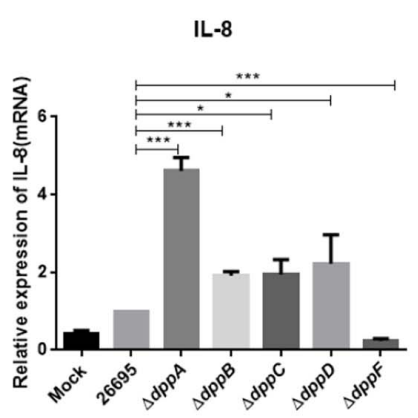

$\mathbf{F}$

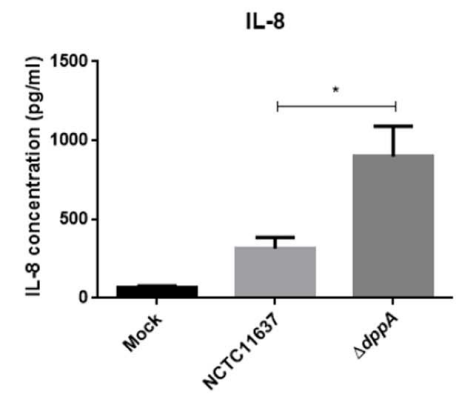

FIGURE 6 | NF-kB activation and IL-8 production induced by $H$. pylori and Dpp transporter mutant strains. (A) NF-kB activity determined by luciferase activity of NF-kB-luc. AGS cells were transfected with a NF-kB luciferase reporter and were infected with $H$. pylori 26695, $\Delta d p p A, \Delta d p p B, \Delta d p p C, \Delta d p p D$, or $\Delta d p p F$, as well as being infected with $H$. pylori NCTC11637 and its isogenic mutant $\triangle d p p A$ (B). Relative luciferase activity represents luciferase activity normalized to mock samples. (C,E) Expression of IL-8 in AGS cells as determined by qPCR or by ELISA (D,F). AGS cells were infected with H. pylori 26,695 and its isogenic Dpp transporter mutant strains, or $\mathrm{H}$. pylori NCTC11637 and $\triangle d p p A$ for $4 \mathrm{~h}$ with an $\mathrm{MOI}$ of 100 . Data represent averages normalized to mock controls and are shown as the mean $\pm \mathrm{SD}(n=3) .{ }^{\star \star \star} P<0.001,{ }^{\star \star} P<0.01,{ }^{\star} P<0.05$.

Our study provided new evidence on the regulation of CagA expression in $H$. pylori, suggesting that the nutrient status of the environment affects CagA expression and H. pylori-related gastric cancer. Specifically, when grown in environments with abundant nutrients, $H$. pylori might express high levels of CagA.

In the early stages of infection, $H$. pylori activates NF- $\mathrm{kB}$ in a CagT4SS-dependent manner. The regulation of T4SS expression might contribute to $H$. pylori-induced inflammatory response in AGS cells. In this study, we found upregulated expression of T4SS components in the $\triangle d p p A$ strain (Figures $\mathbf{4 A}, \mathbf{B}$ ), which was also replicated in a $\triangle d p p C$ strain (Figure 4C). Among these genes, RNA sequencing data and qPCR results showed that genes were upregulated in $\triangle d p p A$ strain to a different degree, which suggested that although these genes are all responsible for the T4SS apparatus, they might be regulated by different mechanisms. A previous study investigated the expression of T4SS and found that these genes responded differently to growth phase, temperature, $\mathrm{pH}$, iron, and cell contact (Yamaoka et al., 2000). Some environmental signals even exert pleiotropic effects on these genes. This suggests that T4SS expression and assembly are controlled by sophisticated mechanisms, but more studies are necessary. The T4SS machinery translocates CagA, ADPheptose, peptidoglycan, and other substrates to host cells (Mobley et al., 1991; Peck et al., 1999; Pfannkuch et al., 2019). Recent studies have shown that ADP-heptose is a novel pathogenassociated molecular marker in $\mathrm{H}$. pylori, and it is the main factor activating NF- $\kappa \mathrm{B}$ in a T4SS-dependent manner (Pfannkuch et al.,
2019). We speculate that T4SS expression is repressed under rich nutrient conditions, and $H$. pylori reduces the translocation of ADP-heptose or other effector molecules. Under poor nutrient condition, T4SS expression is activated and results in a high level of activation of the NF- $\kappa \mathrm{B}$ response.

After $H$. pylori passes through the mucous layer and reaches the gastric mucosa via flagellar movements, OMPs promote close contact between $H$. pylori and gastric epithelial cells. OMPs play important roles in the establishment of colonization (Yuichi et al., 2017; Terbenc et al., 2019). The OMPs in H. pylori have been gradually unveiled, and their cognate interaction partners have been identified. In this study, we found that expression of BabA, HopZ, OipA, and SabA, and bacterial adhesion were upregulated in the $\triangle d p p A$ strain (Figure 6). BabA was the first OMP identified to be involved in the adhesion of $H$. pylori and important for inducing severe inflammation in the stomach. Moreover, studies have shown that T4SS function and CagA translocation are enhanced by BabA (Boren et al., 1993; Ilver et al., 1998; Aspholm-Hurtig et al., 2004). Some studies have shown that the adhesion ability is significantly decreased in oipA mutant strain and hopZ mutant strain in AGS cells (Peck et al., 1999; Dossumbekova et al., 2006). SabA is also important for colonization and induction of inflammation in the stomach (Aspholm et al., 2006). SabA expression is regulated by a $\mathrm{pH}-$ responsive ArsRS two-component signal transduction system (Goodwin et al., 2008). The HopZ gene is involved in the adhesion of $H$. pylori to gastric epithelial AGS cell line in vitro, but 
it did not show any influence on the ability of colonization in the stomachs of guinea pigs (Peck et al., 1999). However, the cognate receptor of HopZ remains unknown. Our study suggested that the Dpp transporter in $H$. pylori plays an important role in the colonization of the stomach.

Besides the virulence factors investigated in this study, our transcriptomic study by RNA sequencing also indicated that the expression of other virulence genes is also altered in the $\triangle d p p A$ background. Flagellar coding genes, including flaA, flaB, $f l i D, f l a G$, and $f l g K$, were significantly upregulated in $\triangle d p p A$ cells (Table 2). Flagellar movement is critical for the initial colonization of $H$. pylori by penetrating gastric mucus layer (Gu, 2017). Indeed, flagellar movement of $H$. pylori is an important factor in mediating high density colonization and severe inflammation. Studies have shown that FlaA and FlaB are necessary for $H$. pylori colonization of animals (Josenhans et al., 1995). ADP-heptose is a lipopolysaccharide synthesis intermediate, which is responsible for $H$. pylori-induced NF$\kappa \mathrm{B}$ activation (Pfannkuch et al., 2019). RNAseq data showed that upregulated expression of majority of LPS-related metabolic genes and the ADP-heptose synthesis gene $g m h B$ in the $\triangle d p p A$ strain (Table 2). GmhB (Hp0860) is an important synthase gene for the synthesis of ADP-heptose by dephosphorylation of D-glycero- $\beta$-d-manno-heptose-1,7-bisphosphate (HBP) (Stein et al., 2017). This suggests that LPS synthesis and ADP-heptose production might be upregulated in $\triangle d p p A$, thereby enhancing $H$. pylori-induced IL-8 production and NF- $\kappa \mathrm{B}$ activation.

In conclusion, we have demonstrated that the Dpp transporter affects the expression of virulence factors such as CagA, T4SS, and OMPs. The Dpp transporter might enable the bacteria to recognize environmental nutrient conditions and change virulence factors such as adhesion and stimulate the release of other virulence factors. Since $H$. pylori causes a chronic infection and is closely related to gastric cancer, our study suggests that when nutrients are limited, and the Dpp transporter fails to transport dipeptides, $H$. pylori enhances its ability to colonize and stimulates an inflammatory response to acquire nutrients from

\section{REFERENCES}

Aspholm, M., Olfat, F., Nordén, J., Sondén, B., Lundberg, C., Sjöström, R., et al. (2006). SabA is the Helicobacter pylori hemagglutinin and is polymorphic in binding to sialylated glycans. PLoS Pathog. 2:e110. doi: 10.1371/journal.ppat. 0020110

Aspholm-Hurtig, M., Dailide, G., Lahmann, M., Kalia, A., Ilver, D., Roche, N., et al. (2004). Functional adaptation of BabA, the Helicobacter pylori ABO blood group antigen binding adhesin. Science 305, 519-522. doi: 10.1126/science. 1098801

Augusto, A. C., Miguel, F., Mendonça, S., Pedrazzoli, J. Jr., and Gurgueira, S. A. (2007). Oxidative stress expression status associated to Helicobacter pylori virulence in gastric diseases. Clin. Biochem. 40, 615-622. doi: 10.1016/ j.clinbiochem.2007.03.014

Backert, S., and Naumann, M. (2010). What a disorder: proinflammatory signaling pathways induced by Helicobacter pylori. Trends Microbiol. 18, 479-486. doi: 10.1016/j.tim.2010.08.003

Boren, T., Falk, P., Roth, K., Larson, G., and Normark, S. (1993). Attachment of Helicobacter pylori to human gastric epithelium mediated by blood group antigens. Science 262, 1892-1895. doi: 10.1126/science.80 18146 the host. Thus, H. pylori tends to repress its ability to stimulate an inflammatory response in gastric epithelial cells while delivering the oncoprotein CagA, which induces gastric cancer.

\section{DATA AVAILABILITY STATEMENT}

The original contributions generated for this study are publicly available. This data can be found here: NCBI Gene Expression Omnibus database (GEO; http://www. ncbi.nlm.nih.gov/geo) under accession number GSE16421 (www.ncbi.nlm.nih.gov/geo/query/acc.cgi?acc=GSE164216).

\section{AUTHOR CONTRIBUTIONS}

YW and FS designed the study. XX, JC, and SF performed the experiments. $\mathrm{XH}$ analyzed the data. YW, XX, and FS wrote the manuscript. All authors have read and approved the submitted version.

\section{FUNDING}

This work was supported by grants from the National Natural Science Foundation of China (Grant Nos. 81701980 and 82072316), the Natural Science Foundation of Fujian Province, China (Grant No. 2019J01295), the Key Projects of Youth Natural Science Foundation of Fujian Colleges and Universities (Grant No. JZ160440), and the Fujian Medical University Talent Startup Fund (XRCZX2017008, XRCZX2017027, and 2017XQ1008).

\section{ACKNOWLEDGMENTS}

We thank LetPub (www.letpub.com) for its linguistic assistance during the preparation of this manuscript.

Brandt, S., Kwok, T., and Hartig, R., et al. (2005). NF-kB activation and potentiation of proinflammatory responses by the Helicobacter pylori CagA protein. P. Natl. Acad. Sci. USA. 102. 9300-9305. doi: 10.1073/pnas.0409873102

Chmiela, M., and Kupcinskas, J. (2019). Review: Pathogenesis of Helicobacter pylori infection. Helicobacter 24 Suppl 1(Suppl. Suppl. 1):e12638. doi: 10.1111/hel. 12638

Davis, G. S., and Mobley, H. L. (2005). Contribution of dppA to urease activity in Helicobacter pylori 26695. Helicobacter 10, 416-423. doi: 10.1111/j.1523-5378. 2005.00348.x

Dossumbekova, A., Prinz, C., Mages, J., Lang, R., Kusters, J. G., Van Vliet, A. H., et al. (2006). Helicobacter pylori HopH (OipA) and bacterial pathogenicity: genetic and functional genomic analysis of hopH gene polymorphisms. J. Infect. Dis. 194, 1346-1355. doi: 10.1086/508426

Garai, P., Chandra, K., and Chakravortty, D. (2017). Bacterial peptide transporters: Messengers of nutrition to virulence. Virulence 8, 297-309. doi: 10.1080/ 21505594.2016.1221025

Gilvarg, C. (1972). "Peptide transport in bacteria," in Peptide transport in bacteria and mammalian gut, Ciba Foundation Symposium, eds K. Elliott and M. O’Connor (Amsterdam: Elsevier).

Goodwin, A. C., Weinberger, D. M., Ford, C. B., Nelson, J. C., Snider, J. D., Hall, J. D., et al. (2008). Expression of the Helicobacter pylori adhesin SabA 
is controlled via phase variation and the ArsRS signal transduction system. Microbiol 154, 2231-2240. doi: 10.1099/mic.0.2007/016055-0

Gu, H. (2017). Role of Flagella in the Pathogenesis of Helicobacter pylori. Curr. Microbiol. 74, 863-869. doi: 10.1007/s00284-017-1256-4

Guillemin, K., Salama, N. R., Tompkins, L. S., and Falkow, S. (2002). Cag pathogenicity island-specific responses of gastric epithelial cells to Helicobacter pylori infection. Proc. Natl. A Sci. Ind. B 99, 15136-15141. doi: 10.1073/pnas. 182558799

Harder, D., Stolz, J., Casagrande, F., Obrdlik, P., Weitz, D., Fotiadis, D., et al. (2008). DtpB (YhiP) and DtpA (TppB, YdgR) are prototypical proton-dependent peptide transporters of Escherichia coli. FEBS J. 275, 3290-3298. doi: 10.1111/j. 1742-4658.2008.06477.x

Hatakeyama, M. (2017). Structure and function of Helicobacter pylori CagA, the first-identified bacterial protein involved in human cancer. Proc. Jpn. Acad. Ser. B Phys. Biol. Sci. 93, 196-219. doi: 10.2183/pjab.93.013

Ilver, D., Arnqvist, A., and Ogren, J. (1998). Helicobacter pylori Adhesin Binding Fucosylated Histo-Blood Group Antigens Revealed by Retagging. Science 279, 373-377. doi: 10.1126/science.279.5349.373

Josenhans, C., Labigne, A., Suerbaum, S. (1995). Comparative ultrastructural and functional studies of Helicobacter pylori and Helicobacter mustelae flagellin mutants: both flagellin subunits, FlaA and $\mathrm{FlaB}$, are necessary for full motility in Helicobacter species. J. Bacteriol. 177, 3010-3020. doi: 10.1007/BF0000007

Kabamba, E. T., Tuan, V. P., and Yamaoka, Y. (2018). Genetic populations and virulence factors of Helicobacter pylori. Infect. Genet. Evol. 60, 109-116. doi: 10.1016/j.meegid.2018.02.022

Karita, M., Tummuru, M. K., Wirth, H. P., and Blaser, M. J. (1996). Effect of growth phase and acid shock on Helicobacter pylori cagA expression. Infect. Immun. 64, 4501-4507. doi: 10.1016/S1380-2933(96)00052-8

Kusters, J. G., van Vliet, A. H., and Kuipers, E. J. (2006). Pathogenesis of Helicobacter pylori infection. Clin. Microbiol. Rev. 19, 449-490. doi: 10.11209/ jim.20.309

Kwok, T., Zabler, D., Urman, S., Rohde, M., Hartig, R., Wessler, S., et al. (2007). Helicobacter exploits integrin for type IV secretion and kinase activation. Nature 449:862. doi: 10.1038/nature06187

Maeda, S., Yoshida, H., Ogura, K., Mitsuno, Y., Hirata, Y., Yamaji, Y., et al. (2000). Helicobacter pylori activates NF- $\mathrm{BB}$ through a signaling pathway involving I $\mathrm{KB}$ kinases, NF-KB-inducing kinase, TRAF2, and TRAF6 in gastric cancer cells. Gastroenterology 119, 97-108. doi: 10.1053/gast.2000.8540

Manson, M. D., Blank, V., Brade, G., and Higgins, C. F. (1986). Peptide chemotaxis in Escherichia coli involves the Tap signal transducer and the dipeptide permease. Nature 321, 253-256. doi: 10.1038/321253a0

Marcus, E. A., Sachs, G., and Scott, D. R. (2018). Acid-regulated gene expression of Helicobacter pylori: Insight into acid protection and gastric colonization. Helicobacter 23:e12490. doi: 10.1111/hel.12490

Merrell, D. S., Goodrich, M. L., Otto, G., Tompkins, L. S., and Falkow, S. (2003a). $\mathrm{pH}$-regulated gene expression of the gastric pathogen Helicobacter pylori. Infect. Immun. 71, 3529-3539. doi: 10.1128/iai.71.6.3529-3539.2003

Merrell, D. S., Thompson, L. J., Kim, C. C., Mitchell, H., Tompkins, L. S., Lee, A., et al. (2003b). Growth phase-dependent response of Helicobacter pylori to iron starvation. Infect. Immun. 71, 6510-6525. doi: 10.1128/iai.71.11.65106525.2003

Mobley, H., Hu, L.-T., and Foxall, P. (1991). Helicobacter pylori urease: properties and role in pathogenesis. Scand. J. Gastroenterol. 26, 39-46. doi: 10.3109/ 00365529109098223

Moraes, P. M., Seyffert, N., Silva, W. M., Castro, T. L., Silva, R. F., Lima, D. D., et al. (2014). Characterization of the Opp peptide transporter of Corynebacterium pseudotuberculosis and its role in virulence and pathogenicity. BioMed Res. Int. 2014:489782. doi: 10.1155/2014/489782

Naumann, M., Sokolova, O., Tegtmeyer, N., and Backert, S. (2017). Helicobacter pylori: A paradigm pathogen for subverting host cell signal transmission. Trends Microbiol. 25, 316-328. doi: 10.1016/j.tim.2016.12.004

Noto, J. M., Gaddy, J. A., Lee, J. Y., Piazuelo, M. B., Friedman, D. B., Colvin, D. C., et al. (2012). Iron deficiency accelerates Helicobacter pylori-induced carcinogenesis in rodents and humans. J. Clin. Invest. 123, 479-492. doi: 10. 1172/JCI64373

Noto, J. M., Lee, J. Y., Gaddy, J. A., Cover, T. L., Amieva, M. R., and Peek, R. M. Jr. (2015). Regulation of Helicobacter pylori virulence within the context of iron deficiency. J. Infect. Dis. 211, 1790-1794. doi: 10.1093/infdis/jiu805
Odenbreit, S., Till, M., Hofreuter, D., Faller, G., and Haas, R. (1999). Genetic and functional characterization of the alpAB gene locus essential for the adhesion of Helicobacter pylori to human gastric tissue. Mol. Microbiol. 31, 1537-1548. doi: 10.1046/j.1365-2958.1999.01300.x

Paulsen, I. T., and Skurray, R. A. (1994). The POT family of transport proteins. Trends Biochem. Sci. 19:404. doi: 10.1016/0968-0004(94)90087-6

Payne, J. W., and Smith, M. W. (1994). Peptide Transport by Micro-organisms. Adv. Microb. Physiol. 36, 1-80. doi: 10.1016/S0065-2911(08)60176-9

Peck, B., Ortkamp, M., Diehl, K. D., Hundt, E., and Knapp, B. (1999). Conservation, localization and expression of HopZ, a protein involved in adhesion of Helicobacter pylori. Nucleic Acids Res. 27, 3325-3333. doi: 10.1093/ nar/27.16.3325

Pfannkuch, L., Hurwitz, R., Traulsen, J., Sigulla, J., Poeschke, M., Matzner, L., et al. (2019). ADP heptose, a novel pathogen-associated molecular pattern identified in Helicobacter pylori. FASEB J. 33, 9087-9099. doi: 10.1096/fj.20180 2555R

Pflock, M., Kennard, S., Finsterer, N., and Beier, D. (2006). Acid-responsive gene regulation in the human pathogen Helicobacter pylori. J. Biotechnol. 126, 52-60. doi: 10.1016/j.jbiotec.2006.03.045

Podbielski, A., and Leonard, B. A. (1998). The group A streptococcal dipeptide permease (Dpp) is involved in the uptake of essential amino acids and affects the expression of cysteine protease. Mol. Microbiol. 28, 1323-1334. doi: 10.1046/ j.1365-2958.1998.00898.x

Rohmer, L., Hocquet, D., and Miller, S. I. (2011). Are pathogenic bacteria just looking for food? Metabolism and microbial pathogenesis. Trends Microbiol. 19, 341-348. doi: 10.1016/j.tim.2011.04.003

Samen, U., Gottschalk, B., Eikmanns, B. J., and Reinscheid, D. J. (2004). Relevance of peptide uptake systems to the physiology and virulence of Streptococcus agalactiae. J. Bacteriol. 186, 1398-1408. doi: 10.1128/JB.186.5.1398-1408.2004

Sanchezzauco, N., Torres, J., Perezfigueroa, G. E., Alvarezarellano, L., Camorlingaponce, M., Gomez, A., et al. (2013). Impact of cagPAI and T4SS on the Inflammatory Response of Human Neutrophils to Helicobacter pylori Infection. PLoS One 8:e64623. doi: 10.1371/journal.pone.0064623

Sanz, Y., Lanfermeijer, F. C., Renault, P., Bolotin, A., Konings, W. N., and Poolman, B. (2001). Genetic and functional characterization of dpp genes encoding a dipeptide transport system in Lactococcus lactis. Arch. Microbiol. 175, 334-343. doi: $10.1007 / \mathrm{s} 002030100270$

Sgouras, D. N., Trang, T. T. H., and Yamaoka, Y. J. H. (2015). Pathogenesis of Helicobacter pylori infection. Helicobacter 20, 8-16. doi: 10.1111/hel.12251

Shao, S.-H., Wang, H., Chai, S.-G., and Liu, L.-M. (2005). Research progress on Helicobacter pylori outer membrane protein. World J. Gastroenterol. WJG 11:3011. doi: 10.3748/wjg.v11.i20.3011

Sharma, C., Hoffmann, S., Darfeuille, F., et al. (2010). The primary transcriptome of the major human pathogen Helicobacter pylori. Nature 464, 250-255. doi: $10.1038 /$ nature 08756

Stein, S. C., Faber, E., Bats, S. H., Murillo, T., Speidel, Y., Coombs, N., et al. (2017). Helicobacter pylori modulates host cell responses by CagT4SSdependent translocation of an intermediate metabolite of LPS inner core heptose biosynthesis. PLoS Pathog. 13:e1006514. doi: 10.1371/journal.ppat. 1006514

Terbenc, A., Jarc, E., Poljak, M., and Homan, M. (2019). Helicobacter pylori virulence genes. World J. Gastroenterol. 25, 4870-4884. doi: 10.3748/wjg.v25. i 33.4870

Tohidpour, A. (2016). CagA-mediated pathogenesis of Helicobacter pylori. Microb. Pathog. 93, 44-55. doi: 10.1016/j.micpath.2016.01.005

Viala, J., Chaput, C., Boneca, I. G., Cardona, A., Girardin, S. E., Moran, A. P., et al. (2004). Nod1 responds to peptidoglycan delivered by the Helicobacter pylori cag pathogenicity island. Nat. Immunol. 5, 1166-1174. doi: 10.1038/ni11 31

Weinberg, M. V., and Maier, R. J. (2007). Peptide transport in Helicobacter pylori: roles of dpp and opp systems and evidence for additional peptide transporters. J. Bacteriol. 189, 3392-3402. doi: 10.1128/JB.01636-06

Yamaoka, Y., Kwon, D. H., and Graham, D. Y. (2000). A Mr 34,000 proinflammatory outer membrane protein (oipA) of Helicobacter pylori. Proc. Natl. A Sci. Ind. B 97, 7533-7538. doi: 10.1073/pnas.130079797

Yuichi, M., Yasutoshi, K., and Yoshio, Y. (2017). Helicobacter pylori Outer Membrane Protein-Related Pathogenesis. Toxins 9:101. doi: $10.3390 /$ toxins 9030101 
Zhang, W.-X., Xie, B.-B., Chen, X.-L., Dong, S., Zhang, X.-Y., Zhou, B.-C., et al. (2010). Cold-adaptation of the Periplasmic Dipeptide-Binding Protein (DppA) from the Deep-sea Psychrophilic Bacterium Pseudoalteromonas sp. SM9913: Domains III and I-2 $\alpha$ at the Entrance of Binding Cleft Play an Important Role. Appl. Environ. Microb. 76, 4354-4361. doi: 10.1128/AEM. 02884-09

Zhou, B., Yang, Y., Chen, T., Lou, Y., and Yang, X. F. (2018). The oligopeptide ABC transporter OppA4 negatively regulates the virulence factor OspC production of the Lyme disease pathogen. Ticks Tick Borne Dis. 9, 1343-1349. doi: 10.1016/j.ttbdis.2018. 06.006
Conflict of Interest: The authors declare that the research was conducted in the absence of any commercial or financial relationships that could be construed as a potential conflict of interest.

Copyright (c) $2021 \mathrm{Xu}$, Chen, Huang, Feng, Zhang, She and Wen. This is an openaccess article distributed under the terms of the Creative Commons Attribution License (CC BY). The use, distribution or reproduction in other forums is permitted, provided the original author(s) and the copyright owner(s) are credited and that the original publication in this journal is cited, in accordance with accepted academic practice. No use, distribution or reproduction is permitted which does not comply with these terms. 